Original scientific paper - Izvorni znanstveni rad

UDK: 637.065

\title{
Do consumption of Kargi Tulum cheese meet daily requirements for minerals and trace elements?
}

doi: 10.15567/mljekarstvo.2015.0307

\begin{abstract}
Seval Sevgi Kirdar ${ }^{1 *}$, Şenol Kose ${ }^{2}$, Ilhan Gun ${ }^{1}$,Elvan Ocak ${ }^{2}$ Özen Kursun ${ }^{3}$
${ }^{1}$ Food Processing Department, Vocational Higher Education School, Mehmet Akif Ersoy University, Burdur, Turkey

${ }^{2}$ Department of Food Engineering, Faculty of Engineering and Architecture,Yuzuncu Y1l University, 65080 Van, Turkey

${ }^{3}$ Department of Food Hygien ana technology, Faculty of Veterinary, Mehmet Akif Ersoy University, 15030 Burdur, Turkey
\end{abstract}

Received - Prispjelo: 25.04.2014. Accepted - Prihvaćeno: 01.06.2015.

\begin{abstract}
The mineral and trace elements of Karg1 Tulum cheese are investigated during the ripening period of 90 days. Calcium, potassium, phosphorus, sodium, magnesium, manganese, copper, zinc and iron quantities were determined by simultaneous inductively coupled plasma optical emission spectrometry (ICP-OES). The effect of maturation time on the sodium, phosphor and potassium content of cheese samples has been found to be statistically significant $(\mathrm{p}<0.05)$. Magnesium and calcium levels during ripening period showed significant statistical difference $(\mathrm{p}<0.01)$. Copper values of cheese samples demonstrated an increase throughout 90-day maturation time. The effect of maturation time on manganese and zinc value has been found to be statistically significant $(\mathrm{p}<0.05)$. According to obtained data, by consuming $100 \mathrm{~g}$ Karg1 Tulum cheese in daily period, an adult can provide a remarkable portion of his/her minerals needs.
\end{abstract}

Key words: minerals, trace metals, ICP-OES, Karg1 Tulum Cheese, ripening

\section{Introduction}

The consumption of cheese is of great nutritional benefit, due in particular to its composition of micronutrients and minerals. The quality of dairy products depends not only on chemical and microbiological parameters, but also on the qualitative and quantitative evaluation of the mineral fraction constituents (Macedo and Malcata, 1997).

The mineral content of cheese is highly variable and depends on numerous factors such as i) initial composition of the milk, which in turn depends upon the breed, stage of lactation and physiological condition of the animal, composition of the feed and environmental factors; ii) cheese making procedures; iii) ripening conditions, which include not only the temperature and relative humidity prevailing in the maturation room, but also protocols of surface salting and washing (Macedo and Malcata, 1997; Merdivan et al., 2004). Tulum cheese is one of the most popular cheese varieties in Turkey. Its name appears to derive from the Turkish word "tulum", which means the sack made from goat's or sheep's skin in which the curds are packaged and ripened (Hayaloglu et al., 2007). Tulum cheese is generally manufactured from raw milk following different processing methods according to the production area, but its production techniques may also change according to local dairies and farmers. There are many of the most important cheese varieties such as 
Savak Tulum cheese (Erzincan), Divle Tulum cheese (Karaman), Cimi Tulum cheese (Antalya), Kargi Tulum cheese (Corum) and Brined Tulum cheese (Izmir) in the Central and Eastern parts of Turkey. Kargi Tulum cheese has more acidic curd properties than rennet curd because of lower rennet $(2-3 \mathrm{~mL} / 100$ $\mathrm{L}$ milk) and low coagulate temperatures $\left(15-18^{\circ} \mathrm{C} /\right.$ $24 \mathrm{~h}$ ). The curd is placed in special cotton cloth bags. These bags are then hung on hooks for another $24 \mathrm{~h}$ in a cooled room at $12-18^{\circ} \mathrm{C}$ to remove whey. After salting of the curd, the cheese is transferred into larger cloth bags $(15-20 \mathrm{~kg})$. This production step goes on daily. The curds are placed in goat skin bags or plastic barriers in other Tulum cheese varieties, except for Izmir Tulum cheese, which is ripened in brine. Consequently, the chemical, biochemical, microbiological and aroma compounds of cheese differs. Kargi Tulum cheese has a yellowish color, a high fat content, and a crumbly, semi hard texture; it is dispersible in the mouth and has a buttery and pungent flavor (Kirdar and Gun, 2012).

The variations witnessed in the mineral agent levels in the studied Tulum cheese samples might be related to the structure of the land where the animal was raised, seasonal changes, the content of the adopted milk and dissimilar techniques followed in manufacturing the cheese. Indeed, in a variety of studies it has been determined that cheese production techniques as well as environmental factors might be influential in the emergence of differentiations between the mineral agent content of cheese forms (Yuzbasi et al., 2009; Bakircioglu et al., 2011; Ozlu et al., 2012).

This study attempts to contribute to the characterization of the mineral and trace elements composition of Kargi tulum cheese during the ripening period.

\section{Materials and methods}

\section{Cheese production}

Kargi tulum is a traditional cheese generally produced from raw milk in the high plateaus of the Kargi district of Corum. Raw milk (15-20 kg) is first filtered and then approximately $75-100 \mathrm{~mL}$ of cheese whey and 5-6 drops of microbial rennet (strength $1: 8.000)$ are added to coagulate the milk. After $24 \mathrm{~h}$ at $15-18^{\circ} \mathrm{C}$ curd is placed in special filter bags made from cotton cloth. These bags are then hung on hooks for another $24 \mathrm{~h}$ in a cooled room at $5-7^{\circ} \mathrm{C}$ to remove whey. Then the bags are placed on wooden troughs and pressed for $24 \mathrm{~h}$ to accelerate whey drainage with regular turning in the same room. The curd is broken up, dry salted (2-2.5\%) and kneaded thoroughly by hand at $15-18^{\circ} \mathrm{C}$. Cheese is transferred into larger cloth bags and packed tightly with a volume of 15-20 kg and again placed in the cooled room. When these bags become completely full, the cheeses are transferred into even larger cloth bags (a perforated-woven cloth made from $100 \%$ cotton) containing $50 \mathrm{~kg}$ of cheese. During the summer
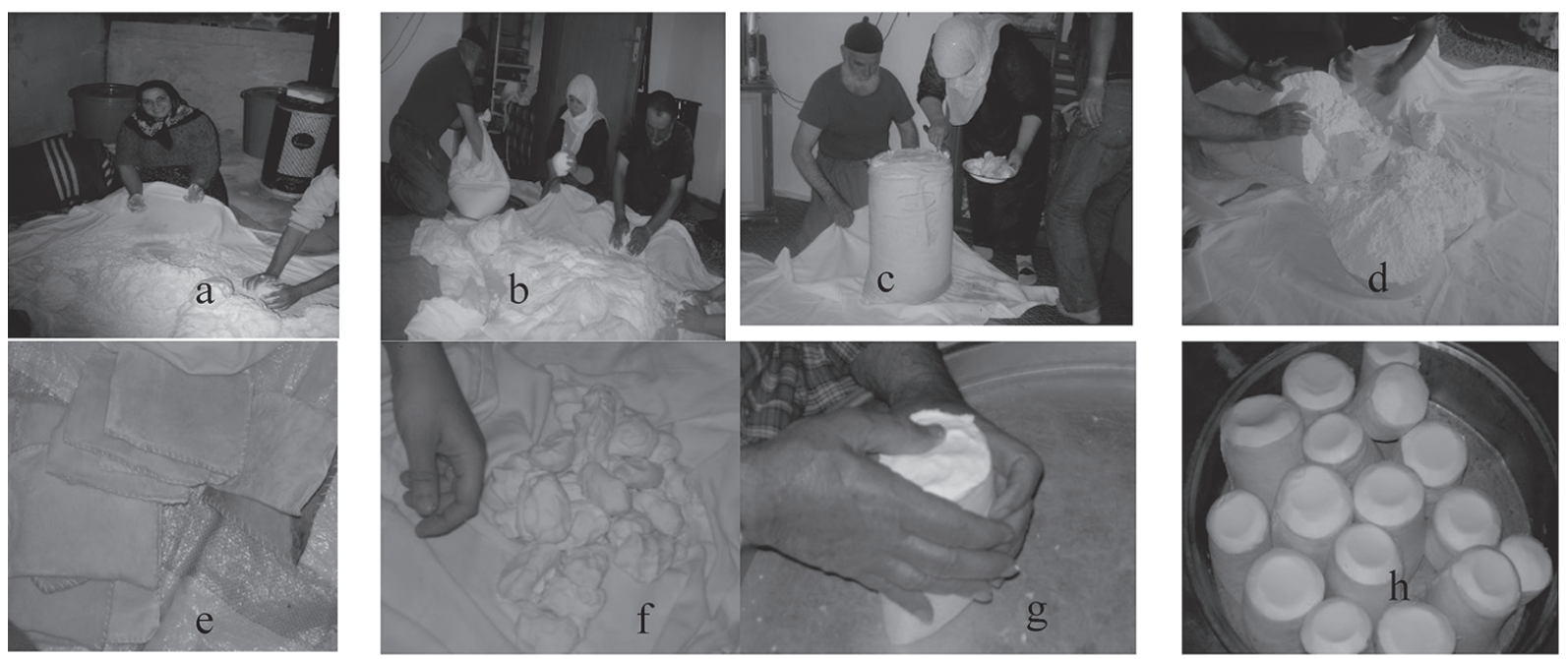

Figure 1. Kargi Tulum cheese production steps: a) dry salted (2-2.5 \%) and kneaded thoroughly by hand; b-c) transferred into even larger cloth bags (50 kg); d) salting and mixing; e) packaging material (tulum); f-g) kneaded thoroughly by hand and stored in tulum; h) Kargi Tulum cheese 
months, the cheese is ripened by transferring it into other bags without air holes at 20-21 day intervals in the cooled rooms of the villages of the high plateau. The cheese is then tightly packed and stored in a skin sack (tulum), with a volume of $250 \mathrm{~g}$ (Figure 1). The cheese is ripened at $6 \pm 1{ }^{\circ} \mathrm{C}$ for 90 days in these skin sacks. Kargi tulum cheese sampling was performed on the first, $30^{\text {th }}, 60^{\text {th }}$ and $90^{\text {th }}$ days of ripening.

\section{Mineral analysis}

The ash content of the cheese was quantified by dry ashing the samples in a muffle furnace at $550{ }^{\circ} \mathrm{C}$ for $24 \mathrm{~h}$. Before samples were placed in the muffle furnace, they were dried in an oven at $105^{\circ} \mathrm{C}$ (IDF, 1992).

Macroelements ( $\mathrm{Ca}, \mathrm{P}, \mathrm{Na}, \mathrm{Mg}$, and K) and microelements ( $\mathrm{Fe}, \mathrm{Cu}, \mathrm{Zn}, \mathrm{Mn}$ ) were analyzed by inductively coupled plasma optical emission spectrometer (ICP-OES) (Perkin Elmer Optima 8000, ABD). Two g of cheese on ash $+8 \mathrm{~mL}$ of $65 \% \mathrm{HNO}_{3}$ added to $2 \mathrm{~mL}$ of $30 \% \mathrm{H}_{2} \mathrm{O}_{2}$ were burned in the microwave Milestone at $200^{\circ} \mathrm{C}$ for 15 minutes. This process was complemented with $50 \mathrm{ml}$ of ultrapure water and the sample was removed from the container. For the mineral analysis, all the reagents were of an analytical grade. All the reagents and samples were prepared in double distilled water. The determina- tions were carried out at 315.8, 214.9, 279.0, 214.9, 589.7, 766.4, 324.7, 259.9 and $213.8 \mathrm{~nm}$ for $\mathrm{Ca}, \mathrm{P}$, $\mathrm{Mg}, \mathrm{Na}, \mathrm{Mn}, \mathrm{K}, \mathrm{Zn}, \mathrm{Fe}$ and $\mathrm{Cu}$, respectively. All the analyses were performed in duplicate.

\section{Statistical analysis}

All of the statistical calculations were performed using SPSS Statistical Software and the obtained values were presented as the mean \pm SE. The evaluation of significance was performed by an analysis of variance, followed by the Duncan test. The significance level of $p<0.05$ was used for determining the statistical differences (Duzgunes and Akman, 1991; Draper and Smith, 1998).

\section{Results and discussion}

The minerals in milk consist of certain agents and in the human diet it is pure ash that plays a vital role in the formation of bone and blood. The ash varied between $3.75-3.95 \%$ in the examined samples. The effect of the maturation process on the increase of the ash content was found to be insignificant $(\mathrm{p}>0.05)$.

The changes in the mineral and trace elements obtained throughout the ripening of Kargi Tulum cheese samples are presented in Tables 1 and 2.

Table 1. Concentration levels of mineral elements $(\mathrm{mg} / \mathrm{kg}$ ) during ripening

\begin{tabular}{cccccc}
\hline $\begin{array}{c}\text { Ripening } \\
\text { time (day) }\end{array}$ & $\mathrm{Na}$ & $\mathrm{Ca}$ & $\mathrm{Mg}$ & $\mathrm{P}$ & $\mathrm{K}$ \\
\hline 1 & $1153.0 \pm 71.8^{\mathrm{a} *}$ & $1778.4 \pm 40.2^{\mathrm{a} * *}$ & $72.6 \pm 6.2^{\mathrm{a} * *}$ & $171.5 \pm 10.2^{\mathrm{a} *}$ & $362.0 \pm 21.9^{\mathrm{a} *}$ \\
\hline 30 & $1429.0 \pm 143.7^{\mathrm{b} *}$ & $2127.0 \pm 20.9^{\mathrm{b} * *}$ & $74.6 \pm 1.9^{\mathrm{b} * *}$ & $184.1 \pm 8.0^{\mathrm{b} *}$ & $369.0 \pm 25.7^{\mathrm{b} *}$ \\
\hline 60 & $1747.0 \pm 264.3^{\mathrm{a} *}$ & $2555.2 \pm 50.6^{\mathrm{c} * *}$ & $91.1 \pm 2.9^{\mathrm{c} * *}$ & $215.2 \pm 2.4^{\mathrm{c} *}$ & $463.8 \pm 108.5^{\mathrm{b} *}$ \\
\hline 90 & $1850.3 \pm 374.8^{\mathrm{a} *}$ & $2499.1 \pm 10.6^{\mathrm{c} * *}$ & $88.9 \pm 2.2^{\mathrm{c} * *}$ & $210.1 \pm 5.8^{\mathrm{c} *}$ & $526.8 \pm 128.0^{\mathrm{c} *}$ \\
\hline
\end{tabular}

*values with different superscripts in columns are significantly $(\mathrm{p}<0.05)$ different

${ }^{* *}$ values with different superscripts in columns are significantly $(\mathrm{p}<0.01)$ different

Table 2. Trace metal concentration during ripening $(\mu \mathrm{g} / \mathrm{g})$

\begin{tabular}{ccccc}
\hline $\begin{array}{c}\text { Ripening } \\
\text { time (day) }\end{array}$ & $\mathrm{Fe}$ & $\mathrm{Mn}$ & $\mathrm{Zn}$ & $\mathrm{Cu}$ \\
\hline 1 & $0.20 \pm 0.02$ & $0.11 \pm 0.0^{\mathrm{a}}$ & $0.28 \pm 0,01^{\mathrm{a}}$ & $0.29 \pm 007$ \\
\hline 30 & $0.26 \pm 0.03$ & $0.14 \pm .0 .01^{\mathrm{a}}$ & $0.29 \pm 0.03^{\mathrm{b}}$ & $0.36 \pm 0,09$ \\
\hline 60 & $0.41 \pm 0.14$ & $0.14 \pm 0.02^{\mathrm{a}}$ & $0.33 \pm 0.03^{\mathrm{c}}$ & $0.39 \pm 0.07$ \\
\hline 90 & $0.58 \pm 0.47$ & $0.19 \pm 0.06^{\mathrm{b}}$ & $0.34 \pm 0.06^{\mathrm{c}}$ & $0.41 \pm 0.21$ \\
\hline
\end{tabular}

values with different superscripts in column are significantly $(\mathrm{p}<0,05)$ different 
Calcium values of the cheese samples exhibited an increase until the $60^{\text {th }}$ day of maturation while they tended to decrease on the $90^{\text {th }}$ day (Table 1). The effect of maturation time on the increase of the calcium value was found to be statistically significant $(\mathrm{p}<0.01)$.

The calcium values of Kargi Tulum cheese are below the values of Tulum, Herby, and Mihalic cheese forms (Demirci, 1989; Kilic et al., 2002; Tarakci and Kucukoner, 2008). Daily calcium intake per person varies between 200 and 1200 $\mathrm{mg}$ in different countries (Arslan et al., 1998; Kirdar, 2008). In Turkey, the quantity is between 400-500 mg (1000 mg during pregnancy and nursing). It has been stated that depending on dietary habits, the body adapts to calcium deficiency. However, in developed states in particular, calcium intake ratios have been kept high and the consumption of milk and dairy products has been promoted. Calcium intake rate suggested for the human diet is closely related to sunshine exposure and protein amounts in the diet (Kilic et al., 2002). The calcium intake rate suggested above for Turkey can be met by consuming $100 \mathrm{~g}$ of Kargi Tulum cheese daily.

The effect of maturation times on the magnesium values of cheese samples was found to be statistically significant $(\mathrm{p}<0.01)$ (Table 1$)$. According to obtained results, the magnesium content of the Kargi Tulum cheese forms was detected to be higher than those found in fresh white cheese, Mihalic cheese, Tulum cheese, Herby cheese, Savak Tulum cheese and Ezine cheese (Demirci, 1989; Arslan et al., 1996; Isleten et al., 2007).

The normal human diet intake ratio of potassium is 2-5.9 g/day and the minimum daily need for potassium varies between 1.6-2.0 g (Saldamli, 1989; Kilic et al., 2002; Kirdar, 2009).

The potassium content of the cheese tended to increase (Table 1). Statistically significant influence of maturation times on the potassium values of cheese samples was found $(\mathrm{p}<0.05)$. According to obtained results, the potassium content of Tulum and Kashar cheese was detected to be higher than the values of Mihalic and Herby cheese (Kilic et al., 2002; Tarakci and Kucukoner, 2008).

Sodium regulates water and acid-base equilibrium, osmotic pressure and the absorbance of nutrients into the membrane. Its daily intake should not exceed 5-6 g. Sodium deficiency triggers such disorders as vomiting, mental dimness, muscle fatigue, pains etc. Excessive sodium might also initiate certain body disorders such as edema and high blood pressure. Additionally, the interrelation between excessive intake of dietary sodium and hypertension is worthy of attention (Saldamli, 1989; De Man, 1990; Miller, 1990; Demirci, 2005). Sodium values indicate that during maturation the sodium values tend to increase $(\mathrm{p}<0.05$; Table 1$)$.

Total sodium quantity in the human body is 200 $\mathrm{g}$ and the daily intake requirement varies between 5-15 g NaCl (3-8 g Na). In a normal human diet, daily sodium intake from food is around $10 \mathrm{~g}$ but in parallel with the habit of using extra salt, this quantity can reach $25 \mathrm{~g}$ and more (Kilic et al., 2002). In the present study, it has been shown that the sodium levels suggested for a healthy person can be met by consuming $100 \mathrm{~g}$ of Kargi Tulum cheese. It is likely that as a result of moisture loss in the cheese weight during maturation, there has been a proportional rise in sodium quantities. The current research findings are in accordance with those of Kilic et al. (2002).

Phosphorus, an abundant element in nature, is also widely present in food. The majority of phosphorus in the human body is present in bones and blood and its quantity varies between 600-900 g, while the daily intake requirement is between 0.8 1.2 g. From a technological aspect, $\mathrm{Ca} / \mathrm{P}$ ratio in food should be around 1. Phosphorus is a vital element not only for bone formation but also for carbohydrate and fat intermediary metabolisms. Cells make use of phosphate bonds as reserve energy sources. A large number of enzymes are activated by phosphorus intake and this element is a vital anion inside cells (Kilic et al., 2002; Metin, 2009).

Phosphorus concentrations during the 90-day period of maturation in cheese samples are shown with their standard errors in Table 1 . In the cheese samples, phosphorus values exhibited an increase until the $60^{\text {th }}$ day of maturation when they reached $215.21 \pm 2.39 \mathrm{mg} / \mathrm{kg}$ while falling to $210.12 \pm 5.75$ $\mathrm{mg} / \mathrm{kg}$ on the $90^{\text {th }}$ day. The effect of maturation times on phosphorus values was found to be statistically significant $(\mathrm{p}<0.05$; Table 1$)$.

World Health Organization (WHO) reports that the daily phosphorus requirement for adults is $400-500 \mathrm{mg}$ while it is $500 \mathrm{mg}$ for children and 500-700 mg for teenagers. It has been noted that in any diet consisting of sufficient amounts of calcium and protein, adequate phosphorus intake can also be seen (Kilic et al., 2002; Kirdar, 2008). In this research, the average phosphorus levels of cheese (100 g) forms could easily meet one third of daily needs. 
Copper is not just a vital element for nutrition physiology but also an equally important catalytic agent (Isleten et al., 2007; Kirdar, 2009). In the copper oxygen state, fat-oxidization that causes the oxide taste in milk and dairy products is catalyzed (Kinik et al., 2003).

In addition, copper plays a huge role in acidic formation and the maturation speed of cheese. Instead of the toxic effect of copper in water, it is believed that due to its huge effect on fat oxidation, it can negatively affect the taste and aroma of milk and dairy products, too. Copper is also likely to affect the formation and maturation stages of cheese (Kirdar, 2009).

Since there is ambiguity concerning the required amounts of copper for humans, no definite value could be set for this trace element. However, for adults it has been reported that $1.5-3 \mathrm{mg} /$ day is both safe and sufficient. Copper quantity in any food product reflects the origin of the product and the conditions in which it was manufactured, processed and made ready for use (Saldamli, 1989).

Copper values of Kargi tulum cheese demonstrated an increase throughout the 90-day maturation period. The effect of maturation times on copper values was found to be statistically insignificant ( $\mathrm{p}>0.05$; Table 2).

Metin (2009) reported that copper quantity within milk is subject to increase due to the interaction of copper with milk containers and the increase of copper in the animal's diet. International Dairy Federation (IDF, 1992) revealed the maximum copper quantity for milk to be $0.4 \mathrm{mg} / \mathrm{kg}$, and for cheese $2.5 \mathrm{mg} / \mathrm{kg}$. Additionally, copper quantities measured in different countries for milk and dairy products are: for milk $0.05 \mathrm{mg} / \mathrm{kg}$ in Holland and $0.42 \mathrm{mg} /$ $\mathrm{kg}$ in the Czech Republic; for cheese $2.5 \mathrm{mg} / \mathrm{kg}$ in Holland and $0.75 \mathrm{mg} / \mathrm{kg}$ in the Czech Republic (IDF, 1992). In the Turkish Food Codex (2002), no quantity of copper has been specified for milk and cheese. On the other hand, it has been observed that the values obtained in this research fit into the 0.05-50 mg/kg limits specified for particular food products in this article. The copper content of Kargi Tulum cheese was similar to the values measured in Savak Tulum cheese and Ezine cheese but lower than the copper content of Herby cheese (Arslan et al., 1996; Isleten et al., 2007). The high copper content might be explained by contamination spread from the containers during the process of transporting and processing cheese milk (Kirdar et al., 2013).
Manganese is an essential cofactor for the enzymes required by fat, glucose and cholesterol metabolisms (Metin, 2009). The human body is comprised of manganese varying between 10-40 mg. It has been suggested that the safe and sufficient quantity of daily manganese from food is $2.0-5.0 \mathrm{mg}$ (Saldamli, 1989).

As the chart shows, it is evident that during the ripening process the manganese values tended to increase. The effect of maturation times on manganese values was found to be statistically significant $(\mathrm{p}<0.05$; Table 2).

The results obtained in this research have been found to be higher than in other studies related to the same subject (Kinik et al., 2003; Mendil, 2006; Isleten et al., 2007; Tarakci and Kucukoner, 2008).

The values obtained regarding iron content of Kargi Tulum cheese samples throughout the maturation period are shown in Table 2. According to the table, the iron content of cheese forms tended to increase. The effect of maturation times on increasing of iron values was found to be statistically insignificant $(\mathrm{p}>0.05)$.

The iron content of the Kargi Tulum cheese sample was found to be higher than the values reported by Isleten et al. (2007). This divergence might be related to the ratios of types of milk in the cheese milk mixture, the feed of the milk animal or contamination caused by the metal containers used during production stages (Merdivan et al., 2004; Kirdar et al., 2013a). There have been different quantities of iron content in different cheese forms (Yuzbasi et al., 2003; Tarakci et al., 2004; Lante et al., 2006). Contamination with iron can easily occur either during milking or processing through contact with iron in the containers, tubes and similar tools. Contamination can also arise from the water used while washing the equipment or during production (Kirdar et al., 2013a,b).

Iron quantities officially approved in different countries are: for milk $0.25 \mathrm{mg} / \mathrm{kg}$ in Holland and $0.30 \mathrm{mg} / \mathrm{kg}$ in Switzerland; for cheese $6.50 \mathrm{mg} / \mathrm{kg}$ in Switzerland and $1 \mathrm{mg} / \mathrm{kg}$ in Holland (IDF, 1992). In the Turkish Food Codex (2002) Article on the Detection of Maximum Levels of Certain Agents in Food Products, no ratio was specified for iron quantities in milk and cheese. However, values specified for particular foods vary between $0.2-25 \mathrm{mg} / \mathrm{kg}$. Iron quantities detected in the present research were found to be higher than this reference limit. 
Research findings exhibit similarities with the findings of other researchers (Kinik et al., 2003; Isleten et al., 2007; Yuzbasi et al., 2009) and the values are lower than the values obtained from Herby cheese, Ezine cheese and Savak Tulum cheese (Arslan et al., 1996; Isleten et al., 2007; Tarakci and Kucukoner, 2008).

Zinc is an essential element for growth and development of the human body. It bears particular importance in the repair of physical injuries and physiological operations in enabling the normal functions of the immune system and metabolism (Metin, 2009). Zinc is an essential mineral present in hair, skin, nail, bones, liver, kidney, muscle, pancreas, spleen and testicles. Ninety percent of total body zinc is present in skeletal muscles and bones (Saldamli, 1989).

Zinc values tended to increase throughout the maturation time. The effect of maturation times on zinc value was found to be statistically significant $(\mathrm{p}<0.05$; Table 2).

The results obtained in the research have been found to be higher than in other studies related to the same topic (Kinik et al., 2003; Mendil, 2006). Using metal milk processing equipment potentially explains the cause of zinc contamination in milk (Kirdar et al., 2013).

According to the Academy of Science (Anonymous, 1989), the daily intake requirement of an adult is $1100-3300 \mathrm{mg} \mathrm{Na}, 800 \mathrm{mg} \mathrm{Ca}, 1875-5625$ mg K, 280-350 mg Mg, 12-15 Zn, 10-15 mg Fe, 2-5 $\mathrm{mg} \mathrm{Mn}$ and 1,5-3 mg Cu. Obtained findings of this research are similar to the arguments of Kilic et al. (2002).

The high copper content might be explained by the contamination spread from the containers during the process of transporting and processing cheese milk. Contamination with iron can easily occur either during milking or processing via contact with iron in the containers, tubes and similar tools. Contamination can also arise from the water used while washing the equipment or during production. The use of metal milk processing equipment is another potential cause of zinc contamination in milk.

\section{Conclusion}

In the present study, period of cheese ripening had a statistically significant effect upon the concentration of sodium, phosphorus, potassium, magnesi- um, calcium, manganese and zinc. It has been shown that the sodium amount suggested for a healthy person can be met by consuming 100 g of Kargi Tulum cheese each day. For phosphorus, it was found that the average levels of cheese forms can sufficiently meet one third of daily needs.

According to these data and detections, by consuming 100 g Kargi Tulum cheese daily, a healthy adult can meet a remarkable proportion of his/her minerals needs.

\section{Acknowledgements}

We would like to extend our gratitude to Kargi Municipality Mayor Mr. Ahmet Hamdi AKPINAR and municipality personnel who wholeheartedly assisted us during our research and also to Yusuf Mihçi, Atiye Yalçin, Nesrin Tolga and their families who showed warm hospitality for three months during our production efforts in Kargi flatland. The authors also thank the Chairmanship of Scientific research projects of Mehmet Akif Ersoy University (Project number: NAP-037-08).

\section{Može li potrošnja Kargi Tulum sira zadovoljiti dnevne potrebe za mineralima $i$ elementima u tragovima?}

\section{Sažetak}

Sadržaj minerala i elemenata u tragovima Kargi Tulum sira je istraživan tijekom zrenja od 90 dana. Kalcij, kalij, fosfor, natrij, magnezij, mangan, bakar, zink i željezo su analizirani induktivnom plazmatskom emisijskom spektrometrijom (ICP-OES). Utjecaj zrenja na koncentraciju natrija, fosfora i kalija u siru bio je statistčki značajan $(\mathrm{p}<0.05)$, a magnezija i kalcija $(\mathrm{p}<0.01)$. Koncentracija bakra se povećala tijekom razdoblja zrenja. Utjecaj zrenja na koncentraciju mangana i cinka također je bio statistički značajan $(\mathrm{p}<0.05)$. S obzirom na utvrđene vrijednosti, evidentno je da konzumacijom 100 g Kargi Tulum sira odrasla osoba može značajno doprinjeti unosu preporučenih doza minerala.

Ključne riječi: minerali, metali u tragovima, ICP-OES, Kargi Tulum sir, zrenje 


\section{References}

1. Anonim (1989): Recommended Dietary Allowences, $10^{\text {th }}$ Ed. Food and Nutrition Board, National Research Council, National Academy of Science.

2. Arslan, A., Güven, A., Gönülalan, Z., Özmen H. (1996): Mineral levels of Savak Tulum cheese. Firat University Journals of Health Science 1082, 265-268 (in Turkish).

3. Bakırcıoglu, D., Kurtuluş, B.Y., Uçan, G. (2011): Determination of some traces levels in cheese samples packaged in plastic ana tin containers by ICP-OES after dry, wet and microwave digestion. Food and Chemical Toxicology 49, 202-207. doi:10.1016/j.fct.2010.10.017

4. De Man, J.M. (1990): Principles of Food Chemistry 2nd ed. Van Mostrand Reinhold, Newyork, USA, p469.

5. Demirci, M. (1989): Mineral and energy value of fresh white cheese. Nature, Agriculture and Forestry of Turkey 13, 952-958 (in Turkish).

6. Demirci, M. (2005): Nutrition. ISBN 975-97146-3-9, İstanbul, p297 (in Turkish).

7. Draper, N.R., Smith, H. (1998): Applied Regression Analysis, ( $3^{\text {rd }}$ ed), Newyork; Wiley.

8. Düzgüneş, O., Akman, O. (1991): Variations Resources. Ankara University Faculty of Agriculture Press,, No: 1200, Ankara, Turkey, pl 46 (in Turkish).

9. IDF (International Dairy Federetaion) (1992): Trace Elements in Milk and Milk Products. Bulletin of the International Dairy Federation, No:278.

10. Hayaloglu, A.A., Cakmakci, S., Brechany, E.Y., Deegan, K.C., McSweeney, P.L.H. (2007): Microbiology, biochemistry, and volatile composition of Tulum cheese ripened in goat's skin or plastic bags. Journal of Dairy Science, 90, 1102-1121. doi: 10.3168/jds.S0022-0302(07)71597-7

11. İsleten., M., Uysal-Pala, Ç., Karagül-Yüceer, Y. (2007): Mineral Content of Ezine cheese. J Food 32,173-179 (in Turkish).

12. Kilic, S., Karagozlu, C., Uysal H., Akbulut, N. (2002): An evaluation on calcium, phosphorus, sodium and potassium levels of some white cheeses in İzmir market. $J$ Food 27, 229-234 (in Tukish).

13. Kinik, Ö., Uysal, H., Akbulut, N. (2003): Trace elements in milk and milk products. Ege University Faculty of Agriculture Press, Bornova, Izmir, Turkey, No. 549. (in Turkish)

14. Kirdar, S.S. (2008): Dairy Chemistry (Lecturer notes) p75.(not published, in Turkish)

15. Kirdar, S.S. (2009): Dairy Technology (Lecturer notes) p20. (not published, in Turkish

16. Kirdar, S.S., Gün, İ. (2012): Karg1 Tulum cheese. J Dairy World 7, 60-62. (in Turkish)

17. Kirdar, S.S., Ocak, E., Köse, S. (2013a): Mineral and Trace Metal Levels of Akçakatik Cheese Collected from Mediterranean Region-Turkey. Asian Journal of Chemistry; 25, 1643-1646. doi: 10.14233/ajchem.2013.13611
18. Kirdar, S.S., Ocak, E., Köse, Ş., Özer, E. (2013b): Seasonal changes in mineral and trace elements of Çanak cheese. Asian Journal of Chemistry, 25, 6177-6180. doi: 10.14233/ajchem.2013.14304

19. Lante, A., Lomolino, G., Cagnin, M., Spettoli, P. (2006): Content and characterization of minerals in milk and in Crescenza and Squqacquerone Italian fresh cheeses by ICP-OES. Food Control 17, 229-233.

20. Mendil, D. (2006): Mineral and trace metal levels in some cheese collected from Turkey. Food Chemistry, 96, 532-537. doi: 10.1016/j.foodchem.2005.03.006

21. Macedo, A.G., Malcata, F.X. (1997): Changes in mineral concentration in Serra cheese during ripening and throughout the cheesemaking season. Journal of Science Food and Agriculture 74, 409-415.

22. Merdivan, M., Yilmaz, E., Hamamci, C., Aygun, R.S. (2004): Basic nutrients and element contents of white cheese of Diyarbakir in Turkey. Food Chemistry 87, 163-171. doi: 10.1016/j.foodchem.2003.11.002

23. Metin, M.(2009): Dairy Technology, Milk Composition and Processing. Ege University Faculty of Agriculture Press, Bornova, Izmir, Turkey, No. 33. (in Turkish)

24. Miller, D.D. (1990): Minerals in Food Chemistry. OR Fennema (Editör) $3^{\text {rd }}$ ed., Marcel Dekker Inc.Newyork, USA, p617-1069.

25. Özlü, H., Atasever, M.A., Urçar, S., Atasever, M.(2012): Mineral Contents and Heavy Metal Contamination in Kashar Cheeses Consumed in Erzurum Province, Turkey. Kafkas University Veterinery Faculty J 18, 205-208. doi: 10.9775/kvfd.2011.5258

26. Saldaml, İ. (1989): Food Chemistry. Hacettepe University Press, Ankara, p526. (in Turkish)

27. Tarakçı, Z., Çoşkun, H., Tunçtürk, Y. (2004) Properties of Herby Cheese. Food Technology Biotechnology 42, 4750 .

28. Tarakç1, Z., Kuçukoner, E. (2008): Comparison of basic nutrients, mineral and heavy metal contents of herby dairy products. International Journal of Food Science and Technology 43, 216-219. doi: 10.1111/j.1365-2621.2006.01411.x

29. Turkish Food Codex (2002): Determination of the Maximum Levels of Certain Contaminants in Foodstuffs. No: 2002/58, Official Gazette: 24857.

30. Yuzbası, N., Sezgin, E., Yıldırım, M., Yıldırım, Z. (2003): Survey of lead, cadmium, iron, copper and zinc in Kashar cheese. Food Additives and Contaminants 20, 464-469. doi: 10.1080/0265203031000094654.

31. Yuzbaşı, N., Sezgin, E., Yıldırım, Z., Yıldırım, M. (2009): Changes in $\mathrm{Pb}, \mathrm{Cd}, \mathrm{Fe}, \mathrm{Cu}$ and $\mathrm{Zn}$ levels during the production of Kasar cheese. Journal of Food Quality 32, 73-83. doi: 10.1111/j.1745-4557.2007.00167.x 